\title{
Long-Run Economic Effects of Changes in the Age Dependency Ratio
}

\author{
Ana Maria Santacreu, Economist
}

mportant demographic changes in the developed world in recent years may have long-run economic consequences. As a result, such changes have started to play a more important role in the design of economic policies.

In a recent blog post, I analyzed changes in the age dependency ratio in the G-7 countries since 1990.1 Thorough analysis of the evolution of this variable and its components is important because the young and old are likely to be more economically dependent on the rest of the population and changes in age composition may affect other areas of the economy.

\section{A decrease in the labor force and an increase in the elderly population could slow economic growth.}

Panel A of the figure plots the annual age dependency ratios for the G-7 countries from 1990 to 2012. The age dependency ratio is the sum of the young population (under age 15) and elderly population (age 65 and over) relative to the working-age population (ages 15 to 64). As the figure shows, dependency ratios have risen in all seven countries in the past 10 years. In some countries, however, the trend started earlier. In Japan, for instance, the increase started in the early 1990s. Changes in the age composition of the population-from increases and/or decreases in the young and elderly populations-drive the dependency ratios. As the figure shows, in all G-7 countries, the elderly populations (Panel B) have increased, while the working-age populations (Panel C) and young populations (Panel D) have decreased slightly or stayed flat. Among those countries, Japan's age dependency ratio increased the most.

Several recent studies ${ }^{2}$ suggest that high dependency ratios may have the following long-term economic consequences:

(i) Saving rates: As workers get close to retirement, they tend to increase their savings through pension plans, healthcare insurance, etc. Also, if younger workers anticipate changes in demographic trends, they could start saving more for the future (by investing more in private pension plans, postponing consumption decisions, or investing in private health insurance). Increased savings could have long-term economic consequences, such as a decrease in long-term interest rates. Eventually, as the elderly start retiring and birth rates start decreasing-as appears to be the recent trend-savings would start decreasing and long-term interest rates would rise. Thus, recent demographic changes could affect saving rates and long-term interest rates.

(ii) Investment rates: If savings decrease, there could be fewer funds to finance investment projects, which could decrease investment in physical capital. Decreased investment could reduce long-term economic growth.

(iii) Housing markets: A growing labor force would increase house prices. A recent article in The Economist finds that since 1960 , house prices in a sample of 10 countries fell by 0.2 percent per year as the age dependency ratio increased. Because the demographic composition of the labor force contributes strongly to the trend in house prices, fewer young people, together with a large increase in the elderly population, would likely result in less investment in the housing market.

(iv) Consumption patterns: An increase in the elderly population could shift consumption from certain goods toward healthcare services and leisure.

In summary, the decrease in the labor force, due to an increase in the elderly population and a decrease in the fertility rate, could translate into lower economic growth. Long-term problems in the developed world caused by an increase in the age dependency ratio could be alleviated by either increasing productivity (to avoid an economic slow-down from a shrinking labor force) or increasing the labor force participation of the elderly (e.g., by increasing the retirement age, as several European countries have done recently, or reducing taxes on the labor income of elderly 


\section{A. Age Dependency Ratio in G-7 Countries}

\section{Percent}

70

65

60

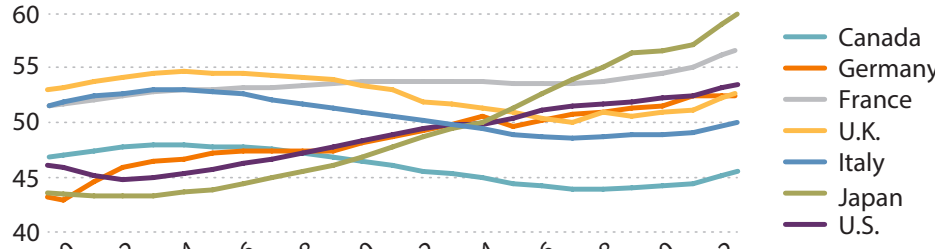

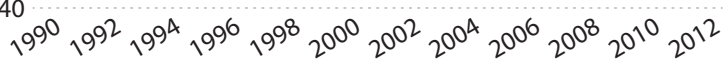

\section{Working-Age Population in G-7 Countries}

Percent

75

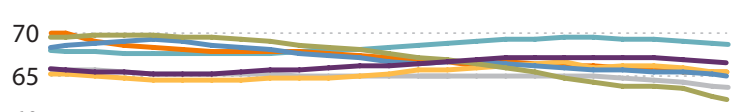

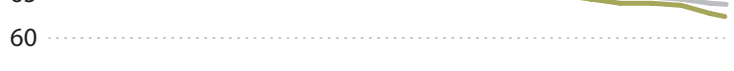

55

45

40

$19^{90} 19^{92} 19^{94} 19^{96} 19^{98} 2^{800} 20^{02} 20^{04} 2^{0} 0^{6} 2^{008} 20^{10} 20^{12}$

\section{B. Elderly Population in G-7 Countries} Percent

30

25

20

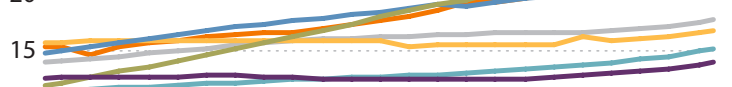

10

5 $19^{90} 19^{92} 19^{94} 1_{99^{6}} 19^{98} 2^{0} 0^{0} 2^{00^{2}} 2^{00^{4}} 2^{00^{6}} 2^{00^{8}} 2^{10} 2^{10^{12}}$

\section{Young Population in G-7 Countries}

Percent

35

30

25

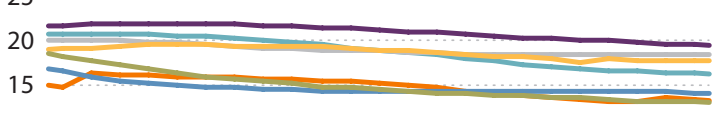

10

5

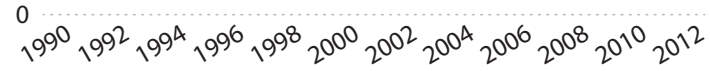

SOURCE: Organisation for Economic Co-operation and Development data and author's calculation.

workers). These economic policies, however, would not reverse the recent demographic trends.

\section{Notes}

'Santacreu, Ana Maria. "How Are Populations Shifting within Developed Countries?" Federal Reserve Bank of St. Louis On The Economy Blog, August 11, 2016; https://www.stlouisfed.org/on-the-economy/2016/august/how-populations-shifting-developed-countries.

${ }^{2}$ Economist. "Vanishing Workers." July 2016, 420(8999), p. 58, http://www.economist.com/news/finance-and-economics/21702477-candebt-fuelled-model-growth-cope-ageing-populations-vanishing. Karp, Nathaniel and Nash-Stacey, Boyd. "Slow Productivity Growth: Cracking the Code." BBVA Research U.S. Economic Watch, August 4, 2016; https://www.bbvaresearch.com/wp-content/uploads/2016/08/160804 US ProductivityGrowth.pdf. 